Огляди літератури, оригінальні дослідження, погляд на проблему, випадок з практики, короткі повідомлення УДК 616.127-005.8:616.126.2-036.8:[61612-008.331.1+616.379-008.64]-085.225.2

DOI 10.11603/1811-2471.2020.v.i4.11755

\title{
ДИНАМІКА ПІСЛЯІНФАРКТНОГО РЕМОДЕЛЮВАННЯ ЛІВОГО ШЛУНОЧКА У ХВОРИХ З АРТЕРІАЛЬНОЮ ГІПЕРТЕНЗІЕЮ ТА ЦУКРОВИМ ДІАБЕТОМ НА ФОНІ ПРИЙОМУ РАМІПРИЛУ І ЗОФЕНОПРИЛУ
}

Тернопільський національний медичний університет імені І. Я. Горбачевського МОз України

РЕзюМЕ. Сьогодні в Україні понад 500 тис. хворих вмирають від серцево-судинних захворювань, що складає 64 \% у загальній структурі смертності. За даними дослідження вітчизняних науковців, загальна захворюваність на інфаркт міокарда в Україні зросте до 2025 року на 24 \%. За останні майже 40 років кількість хворих на цукровий діабет у світі зросла в чотири рази. В Україні значна поширеність артеріальної гіпертензії серед населення обумовила збільшення кількості хвороб системи кровообігу протягом 1991-2016 рр. у 3 рази.

Мета - оцінити динаміку післяінфарктного ремоделювання серця, застосовуючи метод ехокардіоскопії у хворих на інфаркт міокарда в коморбідності з цукровим діабетом та артеріальною гіпертензією.

Матеріал і методи. Нами було обстежено 54 хворих, яким при госпіталізації був встановлений діагноз гострого інфаркту міокарда та які мали супутню патологію - цукровий діабет та артеріальну гіпертензію.

Результати. Порівняння груп пацієнтів з інфарктом міокарда та супутньою патологією - цукровим діабетом та артеріальною гіпертензією - показало, що, не залежно від наявності ЦД, обидва досліджуваних препарати не зумовлювали статистично значущих відхилень величини кінцеводіастолічного індексу (КДІ) у групах досліджуваних пацієнтів ( $\left.p_{1}>0,05 ; p_{2}>0,05\right)$. Порівняння груп пацієнтів, яким призначали різні препарати, показало, що у групі без ЦД після застосування зофеноприлу величина $\mathrm{KCl}$ в пізній термін спостереження виявилася істотно меншою, ніж у групі, в якій застосовували раміприл (на 18,7 \%, $\mathrm{p}_{1}<0,05$ ). За наявності ЦД вплив обох препаратів на величину $\mathrm{KCl}$ був практично однаковим ( $\left.p_{1}>0,05, \mathrm{p}_{2}>0,05\right)$. Порівняння груп пацієнтів залежно від застосованих антигіпертензивних препаратів показало, що в пацієнтів без ЦД і раміприл, і зофеноприл зумовлювали практично однаковий рівень УІ в динаміці обстеженя ( $\left.p_{1}>0,05\right)$. Водночас, у пацієнтів з ЦД через 3 міс. за умов застосування зофеноприлу величина УІ ставала статистично вірогідно більшою, ніж за умов застосування раміприлу (на $\left.19,2 \%, \mathrm{p}_{2}<0,05\right)$. Порівняння обох груп спостереження показало, що через 3 міс. величина ФВ була істотно більшою у хворих з ЦД, порівняно з пацієнтами без ЦД (на $13,0 \%$, р $<0,05$ ).

Порівняння груп пацієнтів залежно від застосованих антигіпертензивних препаратів показало, що в пацієнтів без ЦД через 3 міс. спостереження зофеноприл зумовлював статистично вірогідно більшу ФВ, порівняно з пацієнтами, які отримували раміприл (на $\left.16,8 \%, \mathrm{p}_{1}<0,05\right)$.

Висновки. Проведені нами дослідження виявили диференційний вплив раміприлу та зофеноприлу на продуктивність серця за умов інфаркту міокарда залежно від наявності ЦД. Отримані дані щодо перебудови внутрішньокардіальної гемодинаміки у хворих із супутнім ЦД вказують на вищий ефект від застосування зофеноприлу, тоді як у хворих без супутнього ЦД- раміприлу.

КлючОВІ СлОВА: інфаркт міокарда; раміприл; зофеноприл; цукровий діабет; артеріальна гіпертензія.

Вступ. Сьогодні в Україні понад 500 тис. хворих вмирають від серцево-судинних захворювань, що складає 64 \% у загальній структурі смертності. За даними дослідження вітчизняних науковців, загальна захворюваність на інфаркт міокарда в Україні до 2025 року зросте на 24 \%. За останні майже 40 років кількість хворих на цукровий діабет у світі зросла в чотири рази. В Україні значна поширеність артеріальної гіпертензії серед населення обумовила збільшення кількості хвороб системи кровообігу протягом 1991-2016 рр. у 3 рази $[1,3]$. Тому існує нагальна потреба в покращенні якості кардіологічної медичної допомоги, особливо пацієнтам із гострим інфарктом міокарда та в віддаленому післяінфарктному періоді, оскільки і сьогодні гостро стоїть проблема низького виявлення розвитку таких ускладнень як серцева недостатність, особливо при наявності коморбідності з цукровим діабетом та артеріальною гіпертензією.
Мета - оцінити динаміку післяінфарктного ремоделювання серця, застосовуючи метод ехокардіоскопії у хворих на інфаркт міокарда в коморбідності з цукровим діабетом та артеріальною гіпертензією в гострий період, через 14 діб гострої коронарної події та у віддалений період - через 3 місяці на тлі прийому препаратів групи інгібіторів ангіотензинперетворювального ферменту раміприлу і зофеноприлу.

Матеріал і методи дослідження. Нами було обстежено 54 хворих, яким при госпіталізації був встановлений діагноз гострого інфаркту міокарда та які мали супутню патологію - цукровий діабет (ЦД) та артеріальну гіпертензію (АГ). Середній вік обстежених становив $(56,65 \pm 3,04)$ років. Хворих було поділено на дві групи, в яких до складу комплексної терапії були включені раміприл і зофеноприл. Оцінювали та порівнювали розміри серця за результами ехокардіоскопії, рівень артеріального 
Огляди літератури, оригінальні дослідження, погляд на проблему, випадок з практики, короткі повідомлення тиску, частоту серцевих скорочень та величину подвійного добутку.

Результати й обговорення. Під впливом раміприлу у хворих без ЦД (табл. 1) величина кінцеводіастолічного індексу (КДІ) до 14 доби зростала й перевищувала показник на 1 добу спостереження на $14,8 \%$ ( $<<0,05)$. У пізній термін спостереження показник знижувався й від попередніх істотно не відрізнявся ( $>0,05)$. У хворих на ЦД величина КДІ під впливом раміприлу в динаміці спостереження практично не змінювалася ( $>>0,05)$. Порівняння впливу раміприлу на величину КДІ залежно від наявності ЦД показало, що у пацієнтів без ЦД препарат через 14 діб застосування зумовлював статистично вірогідно більшу величину досліджуваного показника, ніж у пацієнтів з ЦД (на 24,0%, р<0,05).

Натомість застосування зофеноприлу практично не впливало на величину КДІ в динаміці постінфарктного періоду у хворих з ЦД і без нього. Порівняння груп показало, що, не залежно від наявності ЦД, обидва досліджуваних препарати не зумовлювали статистично значущих відхилень величини КДІ у групах досліджуваних пацієнтів $\left(p_{1}>0,05 ; p_{2}>0,05\right)$.

Таблиця 1. Динаміка кінцево-діастолічного індексу (мл·м-2) у хворих на інфаркт міокарда за умов цукрового діабету в гострий період, у віддалений період та через 3 місяці за умов прийому раміприлу і зофеноприлу (М士m)

\begin{tabular}{|c|l|c|c|c|}
\hline \multirow{2}{*}{ Препарат } & \multirow{2}{*}{ Супутня патологія } & \multicolumn{3}{|c|}{ Термін після госпіталізації } \\
\cline { 3 - 5 } & & 1 до6а & 14 ді6 & більше 3 місяців \\
\hline Раміприл & без ЦД $(\mathrm{n}=30)$ & $68,4 \pm 2,5$ & $78,5 \pm 3,5^{1}$ & $73,3 \pm 3,7$ \\
\cline { 2 - 5 } & з ЦД $(\mathrm{n}=10)$ & $63,7 \pm 3,8$ & $63,3 \pm 4,5$ & $67,4 \pm 3,2$ \\
\hline & $\mathrm{P}$ & $>0,05$ & $<0,05$ & $>0,05$ \\
\hline \multirow{2}{*}{ Зофеноприл } & без ЦД (n=29) & $71,0 \pm 3,4$ & $72,9 \pm 3,3$ & $71,2 \pm 4,3$ \\
\cline { 2 - 5 } & з ЦД $(\mathrm{n}=9)$ & $69,9 \pm 6,3$ & $69,0 \pm 8,8$ & $72,7 \pm 3,8$ \\
\hline $\mathrm{P}$ & $>0,05$ & $>0,05$ & $>0,05$ \\
\hline & $\mathrm{P}_{1}$ & $>0,05$ & $>0,05$ & $>0,05$ \\
\hline
\end{tabular}

Примітки:

1. 1,14 - величина статистично вірогідна порівняно з 1 і 14 добами спостереження $(p<0,05)$;

2. $\mathrm{p}_{1}$ - вірогідність відмінностей між групами пацієнтів, які отримували раміприл;

3. р $_{2}$ - вірогідність відмінностей між групами пацієнтів, які отримували зофеноприл.

Величина кінцево-систолічного індексу $(\mathrm{KCl})$ (табл. 2) під впливом раміприлу у хворих без ЦД до 14 доби зростала (на 17,6 \%, порівняно з 1 добою спостереження, $\mathrm{p}<0,05)$. До 14 доби цей показник знижувався й від величини інших термінів суттєво не відрізнявся ( $p>0,05)$. За наявності ЦД показник під впливом раміприлу в динаміці спостереження практично не змінювався ( $>>0,05)$. Порівняння впливу раміприлу залежно від наяв- ності ЦД показало, що через 1 добу спостереження за величиною $\mathrm{KCl}$ не було істотних відмінностей між групами обстежених пацієнтів ( $>>0,05)$, проте через 14 діб і 3 міс. показник зазнав змін $(p<0,05)$. Після застосування зофеноприлу, не залежно від наявності ЦД, теж не відмічали статистично значущих відмінностей величини $\mathrm{KCl}$ як в динаміці спостереження, так і між групами хворих $(p>0,05)$.

Таблиця 2. Динаміка кінцево-систолічного індексу (мл·м-2) у хворих на інфаркт міокарда за умов цукрового діабету в гострий період, у відділений період та через 3 місяці за умов прийому раміприлу і зофеноприлу (М $\pm m)$

\begin{tabular}{|l|l|c|c|c|}
\hline \multirow{2}{*}{ Препарат } & \multirow{2}{*}{ Супутня патологія } & \multicolumn{2}{|c|}{ Термін після госпіталізації } \\
\cline { 3 - 5 } & & 1 доба & 14 діб & більше 3 місяців \\
\hline Раміприл & без ЦД $(\mathrm{n}=30)$ & $35,3 \pm 1,8$ & $41,5 \pm 2,11$ & $39,6 \pm 2,4$ \\
\hline & з ЦД $(\mathrm{n}=10)$ & $30,5 \pm 1,4$ & $31,7 \pm 1,7$ & $33,0 \pm 1,8$ \\
\hline \multirow{2}{*}{ Зофеноприл } & Р & $>0,05$ & $<0,05$ & $<0,05$ \\
\hline & без ЦД $(\mathrm{n}=29)$ & $35,5 \pm 2,2$ & $37,3 \pm 2,1$ & $32,2 \pm 2,5$ \\
\hline & з ЦД $(\mathrm{n}=9)$ & $36,7 \pm 3,1$ & $34,8 \pm 3,4$ & $31,6 \pm 3,8$ \\
\hline & $\mathrm{P}$ & $>0,05$ & $>0,05$ & $>0,05$ \\
\hline & $\mathrm{P}_{1}$ & $>0,05$ & $>0,05$ & $<0,05$ \\
\hline
\end{tabular}


Огляди літератури, оригінальні дослідження, погляд на проблему, випадок з практики, короткі повідомлення

Порівняння груп пацієнтів, яким призначали різні препарати, показало, що у групі без ЦД після застосування зофеноприлу величина $\mathrm{KCl}$ в пізній термін спостереження виявилася істотно меншою, ніж у групі, в якій застосовували раміприл (на $\left.18,7 \%, \mathrm{p}_{1}<0,05\right)$. За наявності ЦД вплив обох препаратів на величину КСІ був практично однаковим $\left(p_{1}>0,05, p_{2}>0,05\right)$.

Зазначена динаміка величини КДІ та $\mathrm{KCl}$ під впливом досліджуваних препаратів зумовлювала певні відхилення величини ударного індексу (УІ) хворих залежно від наявності ЦД (табл. 3). Так, застосування раміприлу у хворих без ЦД зумовлювало статистично значуще зростання величини УІ через 14 діб, порівняно з 1 (на 11,4%, р<0,05). Згодом показник знижувався й істотно від значень у попередній термін спостереження не відрізнявся. У пацієнтів з ЦД раміприл не викликав істотних відхилень величини УІ $(p<0,05)$. Порівняння впливу раміприлу на величину УІ залежно від наявності ЦД показало, що через 14 діб показник виявися істотно більшим у пацієнтів без ЦД (на 17,1%, p<0,05).

Таблиця 3. Динаміка ударного індексу (мл·м-2) у хворих на інфаркт міокарда за умов цукрового діабету в гострий період, у відділений період та через 3 місяці за умов прийому раміприлу і зофеноприлу (M $\pm \mathrm{m})$

\begin{tabular}{|l|l|c|c|c|}
\hline \multirow{2}{*}{ Препарат } & \multirow{2}{*}{ Супутня патологія } & \multicolumn{3}{|c|}{ Термін після госпіталізації } \\
\cline { 3 - 5 } & & 1 доба & 14 діб & більше 3 місяців \\
\hline Раміприл & без ЦД $(\mathrm{n}=30)$ & $33,2 \pm 1,0$ & $37,0 \pm 1,5^{1}$ & $34,1 \pm 1,5$ \\
\cline { 2 - 5 } & з ЦД $(\mathrm{n}=10)$ & $33,3 \pm 2,7$ & $31,6 \pm 2,8$ & $34,4 \pm 2,1$ \\
\hline \multirow{2}{*}{ Зофеноприл } & $\mathrm{P}$ & $>0,05$ & $<0,05$ & $>0,05$ \\
\hline & без ЦД $(\mathrm{n}=29)$ & $35,5 \pm 1,8$ & $35,7 \pm 1,6$ & $38,9 \pm 2,6$ \\
\hline & з ЦД $(\mathrm{n}=9)$ & $33,2 \pm 2,6$ & $36,6 \pm 2,7$ & $41,0 \pm 2,21$ \\
\hline $\mathrm{P}$ & $>0,05$ & $>0,05$ & $>0,05$ \\
\hline & $\mathrm{P}_{1}$ & $>0,05$ & $>0,05$ & $>0,05$ \\
\hline
\end{tabular}

У свою чергу, зофеноприл у пацієнтів без ЦД не викликав істотних відхилень величини УІ в динаміці дослідження ( $p>0,05)$. Натомість, у пацієнтів з ЦД препарат зумовив поступове зростання величини УІ, яке через 3 міс. застосування статистично вірогідно перевищило показник на 1 добу (на 23,5\%, р<0,05).

Порівняння груп пацієнтів залежно від застосованих антигіпертензивних препаратів показало, що в пацієнтів без ЦД і раміприл, і зофеноприл зумовлювали практично однаковий рівень УІ в динаміці обстеження $\left(p_{1}>0,05\right)$. Водночас, у пацієнтів з ЦД через 3 міс. за умов застосування зо- феноприлу величина УІ ставала статистично вірогідно більшою, ніж за умов застосування раміприлу (на $\left.19,2 \%, p_{2}<0,05\right)$.

За умов застосування досліджуваних препаратів у хворих на інфаркт міокарда динаміка ФВ була наступною (табл. 4). Під впливом раміприлу у хворих без ЦД величина ФВ протягом усього терміну спостереження поступово знижувалася, проте результат виявився статистично не значущим $(p>0,05)$. Аналогічно стабільною під впливом раміприлу була ФВ й у пацієнтів з ЦД (р>0,05). Порівняння цих груп спостереження не виявило істотних відмінностей протягом усього терміну лікування ( $>0,05)$.

Таблиця 4. Динаміка ФВ (\%) у хворих на інфаркт міокарда за умов цукрового діабету в гострий період,

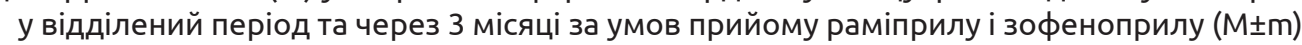

\begin{tabular}{|c|l|c|c|c|}
\hline \multirow{2}{*}{ Препарат } & \multirow{2}{*}{ Супутня патологія } & \multicolumn{2}{|c|}{ Термін після госпіталізації } \\
\cline { 3 - 5 } & & 1 доба & 14 діб & більше 3 місяців \\
\hline Раміприл & без ЦД $(\mathrm{n}=30)$ & $49,2 \pm 1,2$ & $47,5 \pm 1,1$ & $46,9 \pm 1,0$ \\
\cline { 2 - 5 } & з ЦД $(\mathrm{n}=10)$ & $51,7 \pm 1,4$ & $50,0 \pm 1,2$ & $50,8 \pm 2,0$ \\
\hline \multirow{2}{*}{ Зофеноприл } & $\mathrm{P}$ & $>0,05$ & $>0,05$ & $>0,05$ \\
\hline & без ЦД $(\mathrm{n}=29)$ & $50,3 \pm 1,3$ & $49,2 \pm 1,2$ & $54,8 \pm 1,714$ \\
\cline { 2 - 5 } & з ЦД $(\mathrm{n}=9)$ & $48,3 \pm 2,4$ & $50,2 \pm 3,1$ & $48,5 \pm 2,5$ \\
\hline $\mathrm{P}$ & $>0,05$ & $>0,05$ & $<0,05$ \\
\hline & $\mathrm{P}_{1}$ & $>0,05$ & $>0,05$ & $<0,05$ \\
\hline
\end{tabular}


Огляди літератури, оригінальні дослідження, погляд на проблему, випадок з практики, короткі повідомлення

Під впливом зофеноприлу величина ФВ у хворих без ЦД мала коливальний характер зі зниженням через 14 діб та підвищенням через 3 міс. спостереження, що виявилося статистично вірогідно більшим, порівняно з попереднім терміном спостереження (на $11,4 \%, \mathrm{p}<0,05$ ). Порівняння цих груп спостереження показало, що через 3 міс. величина ФВ була істотно більшою у хворих з ЦД, порівняно з пацієнтами без ЦД (на 13,0\%, p<0,05).

Порівняння груп обстежених залежно від застосованих антигіпертензивних препаратів показало, що в пацієнтів без цД через 3 міс спостереження зофеноприл зумовлював статистично вірогідно більшу ФВ, порівняно з пацієнтами, які отримували раміприл (на $\left.16,8 \%, \mathrm{p}_{1}<0,05\right)$.

На тлі застосування антигіпертензивних препаратів відмічали відхилення величини ЧСС (табл. 5). Уведення раміприлу у хворих без ЦД через 14 діб зумовлювало статистично значуще зниження величини чСС порівняно з 1 добою спостереження (на 14,0\%, p<0,05). Через 3 міс. показник зростав й статистично значуще від попередніх термінів не відрізнявся ( $>>0,05)$. За умов ЦД раміприл зумовлював стабільне зниження ЧСС через 14 діб і 3 міс. спостереження порівняно з 1 добою (відповідно на 19,5 і 14,5 \%, p<0,05). Незважаючи на це, відмінності між групами хворих, які отримували раміприл, незалежно від наявності супутнього ЦД, суттєво не змінювалися $(p>0,05)$.

Застосування зофеноприлу у хворих без ЦД теж супроводжувалося зниженням величини ЧСС через 14 діб і 3 міс. спостереження (відповідно на 11,8 i $14,6 \%$, p<0,05). Водночас на тлі ЦД зофеноприл теж зумовлював зниження ЧСС, проте показник виявився статистично значущим через 3 міс. спостереження порівняно 1 добою (на 9,2\%, p<0,05).

Таблиця 5. Динаміка ЧСС (уд·хв-1) у хворих на інфаркт міокарда за умов цукрового діабету в гострий період,

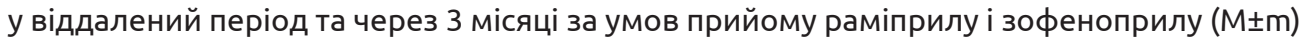

\begin{tabular}{|c|c|c|c|c|}
\hline \multirow{2}{*}{ Препарат } & \multirow{2}{*}{ Супутня патологія } & \multicolumn{3}{|c|}{ Термін після госпіталізації } \\
\hline & & 1 доба & 14 діб & більше 3 місяців \\
\hline \multirow[t]{2}{*}{ Раміприл } & без ЦД (n=30) & $78,4 \pm 2,9$ & $67,4 \pm 1,7^{1}$ & $72,6 \pm 2,2$ \\
\hline & з ЦД (n=10) & $86,0 \pm 3,3$ & $69,2 \pm 2,6^{1}$ & $73,5 \pm 1,8^{1}$ \\
\hline \multicolumn{2}{|r|}{$\mathrm{P}$} & $>0,05$ & $>0,05$ & $>0,05$ \\
\hline \multirow[t]{2}{*}{ Зофеноприл } & без ЦД (n=29) & $78,0 \pm 1,8$ & $68,8 \pm 1,6^{1}$ & $66,6 \pm 1,5^{1}$ \\
\hline & з ЦД (n=9) & $82,9 \pm 2,5$ & $76,7 \pm 2,6$ & $75,2 \pm 2,2^{1}$ \\
\hline \multicolumn{2}{|r|}{$\mathrm{P}$} & $>0,05$ & $<0,05$ & $<0,05$ \\
\hline \multicolumn{2}{|r|}{$p_{1}$} & $>0,05$ & $>0,05$ & $<0,05$ \\
\hline \multicolumn{2}{|r|}{$\mathrm{P}_{2}$} & $>0,05$ & $<0,05$ & $>0,05$ \\
\hline
\end{tabular}

Порівняння груп пацієнтів залежно від застосованих антигіпертензивних препаратів показало, що в пацієнтів без ЦД зофеноприл через 3 міс. спостереження зумовлював статистично вірогідно меншу ЧСС, порівняно з пацієнтами, які отримували раміприл (на 8,2 \%, $\mathrm{p}_{1}<0,05$ ). Водночас, у пацієнтів з ЦД величина чСС була істотно меншою через 14 діб за умов застосування раміприлу, порівняно з зофеноприлом (на 9,8 \%, $\mathrm{p}_{2}<0,05$ ).
Під впливом досліджуваних препаратів відмічали відмінності й за величиною СІ (табл. 6). Якщо за умов застосування раміприлу в пацієнтів без ЦД величина $\mathrm{Cl}$ практично не змінювалася в динаміці лікування ( $>>0,05)$, то у хворих із ЦД показник через 14 діб ставав статистично вірогідно меншим, ніж через 1 добу спостереження (на 29,4 \%, р<0,05). у цей же термін показник виявився істотно меншим, ніж у хворих без ЦД (на 20,2 \%, р<0,05).

Таблиця 6. Динаміка $\mathrm{Cl}\left(л \cdot \mathrm{xB}^{-1} \cdot \mathrm{M}^{2}\right)$ у хворих на інфаркт міокарда за умов цукрового діабету в гострий період,

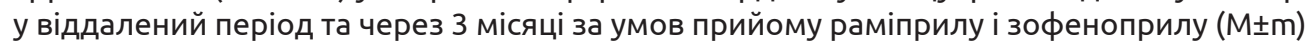

\begin{tabular}{|l|l|c|c|c|}
\hline \multirow{2}{*}{ Препарат } & \multirow{2}{*}{ Супутня патологія } & \multicolumn{3}{|c|}{ Термін після госпіталізації } \\
\cline { 3 - 5 } & & 1 до6а & 14 ді6 & більше 3 місяців \\
\hline Раміприл & без ЦД $(\mathrm{n}=30)$ & $2,60 \pm 0,12$ & $2,53 \pm 0,16$ & $2,43 \pm 0,14$ \\
\cline { 2 - 5 } & з ЦД $(\mathrm{n}=10)$ & $2,86 \pm 0,20$ & $2,02 \pm 0,12^{1}$ & $2,47 \pm 0,22$ \\
\hline \multirow{2}{*}{ Зофеноприл } & $\mathrm{P}$ & $>0,05$ & $<0,05$ & $>0,05$ \\
\hline & без ЦД (n=29) & $2,79 \pm 0,18$ & $2,45 \pm 0,12$ & $2,59 \pm 0,18$ \\
\hline & з ЦД $(\mathrm{n}=9)$ & $2,54 \pm 0,29$ & $2,69 \pm 0,25$ & $3,06 \pm 0,191$ \\
\hline $\mathrm{P}$ & $>0,05$ & $>0,05$ & $>0,05$ \\
\hline & $\mathrm{P}_{1}$ & $>0,05$ & $>0,05$ & $>0,05$ \\
\hline
\end{tabular}


Огляди літератури, оригінальні дослідження, погляд на проблему, випадок з практики, короткі повідомлення

Застосування зофеноприлу у хворих без цД теж не викликало суттєвих відмінностей величини $\mathrm{Cl}$ в динаміці спостереження ( $>>0,05)$. Водночас у хворих з ЦД показник через 3 міс. зростав, порівняно з 1 добою спостереження (на 20,5\%, р<0,05).

Порівняння груп пацієнтів залежно від застосованих антигіпертензивних препаратів показало, що в обстежених без ЦД не відмічали істотних відмінностей за величиною $\mathrm{Cl}$ після використання раміприлу i зофеноприлу ( $\left.p_{1}>0,05\right)$, водночас на тлі ЦД зофеноприл через 14 діб і 3 міс. зумовлював істотно більший Сl, ніж раміприл (відповідно на 33,2 і $\left.23,9 \%, \mathrm{p}_{2}<0,05\right)$.

Висновки. Отримані результати свідчать про те, що раміприл у хворих на інфаркт міокарда без ЦД через 14 діб сприяє збільшенню продуктивності серця за рахунок збільшення УІ, що обумовлено суттєвим зростанням у цей термін КДІ і, незважаючи на помірне зростання $\mathrm{KCl}$, вказує на активне залучення механізму Франка - Старлінга. За умов застосування зофеноприлу також збільшується продуктивність роботи серця, проте у хворих із цД через 3 міс. Варто зазначити, що збільшення УІ в цей термін зумовлено зростанням КДІ та зниженням $\mathrm{KCl}$. Хоча статистично ці відхилення були невірогідними ( $>0,05)$, можна припустити, що зофеноприл у хворих на інфаркт міокарда з ЦД сприяє як помірному розтягненню волокон міокарда, так i зростанню його контрактильності. Привертає увагу також той факт, що на фоні зофеноприлу у хворих без ЦД через 3 міс. застосування відмічають істотно менший $\mathrm{KCl}$ та більшу ФВ, ніж після застосування раміприлу, що додатково свідчить про посилення зофеноприлом інотропної функції міокарда.
Обидва препарати при тривалому застосуванні сприяють зниженню величини ЧСС, що було найбільше виражено після застосування зофеноприлу через 3 міс. у хворих без ЦД та раміприлу у хворих із ЦД через 14 діб спостереження.

Раміприл протягом 14 діб застосування сприяє зниженню величини СІ у хворих на ЦД. Останнє свідчить про перебудову центральної гемодинаміки за гіпокінетичним типом і може мати певне адаптаційне значення в умовах інфаркту міокарда. Разом з тим, зофеноприл у хворих із ЦД через 3 міс. супроводжується перебудовою центральної гемодинаміки за гіперкінетичним типом, що, ймовірно, свідчить про збільшення фукціональної здатності міокарда.

Проведені нами дослідження виявили диференційний вплив раміприлу та зофеноприлу на продуктивність серця за умов інфаркту міокарда залежно від наявності ЦД. Отримані дані щодо перебудови внутрішньокардіальної гемодинаміки у хворих з супутнім ЦД вказують на вищий ефект від застосування зофеноприлу, тоді як у хворих без супутнього ЦД-раміприлу.

Перспективи подальших досліджень. Питання лікування пацієнтів з інфарктом міокарда широко обговорюються у сучасних наукових публікаціях і дослідженнях, проте оптимальний препарат для віддаленого запобігання розвитку серцевої недостатності остаточно не визначений. Тому усі спроби покращити ефективність терапії даного контингенту хворих, особливо в умовах мікст-патології, мають велику перспективу для подальших досліджень.

\section{ЛІТЕРАТУРА}

1. Державна служба статистики України, 2019. Населення України за 2018 рік. Демографічний щорічник «Коефіцієнти смертності за основними класами причин смерті, статтю померлих» - URL: http://www.ukrstat. gov.ua/druk/publicat/kat_u/2019/zb/12/zb_ukr_2018.pdf

2. Impared glucose tolerance or newly diagnosed diabetes mellitus diagnosed during admission adversely affects prognosis after myocardial infarction: an observational study / Anish George, Raghav T. Bhatia, Gill L. Buchanan [et al.] // Plos One. - 2015. - Vol. 10, No 11. P. 1-11.

3. Серцево-судинні захворювання. Класифікація, стандарти діагностики та лікування / Всеукр. асоц. кар- діологів ; За ред. В. М. Коваленка [та ін.]. - 3-тє вид., переробл. і допов. - Київ : Моріон, 2018. - 223 с.

4. Патофізіологічні механізми розвитку і прогресування міокардіальної дисфункції у пацієнтів із гострим інфарктом міокарда / В. П. Іванов, О. В. Щербак, О. Ф. Білонько, В. П. Щербак // Укр. Мед. Часопис. 2015. - T. 4, № 108. - C. 26-30.

5. Which heart failure patients profit from natriuretic peptide guided therapy? A meta-analysis from individual patient data of randomized trials / Hans-Peter Brunner-La Rocca, Luc Eurlings, A. Mark Richards [et al.] // European Journal of Heart Failure. - 2015. - Vol. 17, Issue 12. - P.1252-1261. 
Огляди літератури, оригінальні дослідження, погляд на проблему, випадок з практики, короткі повідомлення REFERENCES

1. Coefficient of mortality according to the main causes of death, sex of the died people. State department of statistics in Ukraine, 2019. Inhabitants of Ukraine in 2018. Lemographycal situation in Ukraine every year. Retrieved from: http://www.ukrstat.gov.ua/druk/publicat/kat_u/2019/ zb/12/zb_ukr_2018.pdf [in Ukrainian].

2. George, A., Raghav, T., Bhatia, T., \& Gill Buhanan, L. (2015). Impared glucose tolerance or newly diagnosed diabetes mellitus diagnosed during admission adversely affects prognosis after myocardial infarction: an observational study. Plos One, (10) 11, 1-11.

3. Kovalenko, V.M. (2018). Sertsevo-sudynni zakhvoriuvannia. Klayfikatsiia, standarty diahnostyky ta likuvannia [Cardio-vascular diseases. Classification, standards in

diagnostic and treatment process]. Kyiv: Morion [in Ukrainian].

4. Ivanov, B.P., Shcherbak, O.F., \& Bilonko, V.P. (2015). Patofiziolohichni mekhanizmy rozvytku i prohresuvannia miokardialnoi dysfunktii u patsiientiv iz hostrym infarktom miokarda [Pathophysiological mechanisms of development and progression of myocardial dysfunction in patients with myocardial infarction]. Ukr. med. chasopys Ukrainian Medical Review, 4 (108), 26-30 [in Ukrainian].

5. Hans-Peter Brunner-La Rocca, Luc Eurlings, \& Mark Richards, A. (2015). Which heart failure patients profit from natriuretic peptide guided therapy? A meta-analysis from individual patient data of randomized trials. European Journal of Heart Failure, 17 (12), 1252-1261.

\section{ДИНАМИКА ПОСТИНФАРКТНОГО РЕМОДЕЛИРОВАНИЯ ЛЕВОГО ЖЕЛУДОЧКА У БОЛЬНЫХ АРТЕРИАЛЬНОЙ ГИПЕРТЕНЗИЕЙ И САХАРНЫМ ДИАБЕТОМ НА ФОНЕ ПРИЕМА РАМИПРИЛА И ЗОФЕНОПРИЛА}

๔Л. Ю. Бидованец

\section{Тернопольский национальный медицинский университет имени И. Я. Горбачевского МОЗ Украины}

РЕЗЮМЕ. Сегодня в Украине более 500 тыс. больных умирают от сердечно-сосудистых заболеваний, что составляет 64 \% в общей структуре смертности. По данным исследования отечественных ученых,общая заболеваемость инфарктом миокарда в Украине возрастет к 2025 году на 24 \%. За последние почти 40 лет количество больных сахарным диабетом в мире выросло в четыре раза. В Украине значительная распространенность артериальной гипертензии среди населения обусловила увеличение количества болезней системы кровообращения в течение 1991-2016 годов в 3 раза.

Цель - оценить динамику постинфарктного ремоделирования сердца, применяя метод эхокардиоскопии, у больных инфарктом миокарда в коморбидности с сахарным диабетом и артериальной гипертензией.

Материал и методы. Нами было обследовано 54 больных, которым при госпитализации был установлен диагноз острого инфаркта миокарда, и имевших сопутствующую патологию - сахарный диабет и артериальную гипертензию.

Результаты. Сравнение групп пациентов с инфарктом миокарда и сопутствующей патологией - сахарным диабетом (СД) и артериальной гипертензией - показало, что не зависимо от наличия СД, оба исследуемых препарата не обусловливали статистически значимых отклонений величины конечно-диастолического индекса (КДИ) в группах исследуемых пациентов $\left(p_{1}>0,05 ; p_{2}>0,05\right)$. Сравнение групп пациентов, которым назначали различные препараты, показало, что в группе без СД после применения зофеноприла величина конечно-систолического индекса (КСИ) в поздние сроки наблюдения оказалась существенно меньше, чем в группе обследованных, у которых применяли рамиприл (на 18,7\%, $\left.\mathrm{p}_{1}<0,05\right)$. При наличии СД влияние обоих препаратов на величину КСИ было практически одинаковым ( $\left.p_{1}>0,05, p_{2}>0,05\right)$. Сравнение групп пациентов в зависимости от применяемых антигипертензивных препаратов показало, что у пациентов без СД и рамиприл, и зофеноприл обусловили практически одинаковый уровень ударного индекса (УИ) в динамике обследования $\left(\mathrm{p}_{1}>0,05\right)$. В то же время, у пациентов с СД через 3 мес. в условиях применения зофеноприла величина УИ становилась статистически достоверно большей, чем в условиях применения рамиприла (на 19,2 \%, p <0,05). Сравнение обеих групп наблюдения показало, что через 3 мес. величина фракции выброса (ФВ) левого желудочка была существенно большей у больных с СД, по сравнению с пациентами без СД (на 13,0%, p<0,05). Сравнение групп пациентов в зависимости от применяемых антигипертензивных препаратов показало, что у пациентов без СД через 3 мес. наблюдения зофеноприл предопределял статистически достоверно большую ФВ левого желудочка, по сравнению с пациентами, получавшими рамиприл (на $16,8 \%, \mathrm{p}_{1}<0,05$ ).

Выводы. Проведенные нами исследования выявили дифференцированное влияние рамиприла и зофеноприла на производительность сердца в условиях инфаркта миокарда в зависимости от наличия СД. Полученные данные по перестройке внутрикардиальной гемодинамики у больных с сопутствующим СД указывают на более высокий эффект от применения зофеноприла, в то время как у больных без сопутствующего СД - рамиприла.

КЛЮЧЕВЫЕ СЛОВА: инфаркт миокарда; рамиприл; зофеноприл; сахарный диабет; артериальная гипертензия. 


\section{DYNAMICS OF LEFT VENTRICULAR REMODELING AFTER MYOCARDIAL INFARCTION IN PATIENTS WITH HYPERTENSION AND DIABETES MELLITUS ON THE BACKGROUND OF TAKING RAMIPRIL AND ZOFENOPRIL}

\section{@L. Y. Bidovanets}

\section{Horbachevsky Ternopil National Medical University}

SUMMARY. Today in Ukraine more than 500 thousand patients die from cardiovascular diseases, which is $64 \%$ of the total mortality structure. According to a study of local scientists, the overall incidence of myocardial infarction in Ukraine will increase by 2025 on $24 \%$. In the last almost 40 years, the number of people with diabetes in the world has quadrupled. In Ukraine, the significant prevalence of hypertension among the population has led to an increase in the number of diseases of the circulatory system during 1991-2016 in 3 times.

The aim - to assess the dynamics of postinfarction remodeling heart, using the method of echocardioscopy in patients with myocardial infarction in comorbidity with diabetes mellitus and hypertension.

Material and Maethods. We examined 54 patients who at hospitalization was diagnosed with acute myocardial infarction and who had concomitant pathology with diabetes mellitus and hypertension.

Results. Comparison of groups of patients with myocardial infarction and concomitant pathology with diabetes mellitus and hypertension showed, that regardless the presence of diabetes, both drugs did not cause statistically significant deviations in end-diastolic index in groups. Comparison of groups with patients that was prescribed different drugs showed that in the group without diabetes after the use of zofenopril, the value of end-systolic index in the late period of observation was significantly lower than in the group in which ramipril was used $\left(18.7 \%, p_{1}<0.05\right)$. In the presence of diabetes, the effect of both drugs on the value of end-systolic index was almost the same $\left(p_{1}>0.05, p_{2}>0.05\right)$. Comparison of groups of patients depending on the used antihypertensive drugs showed that in patients without diabetes ramipril and zofenopril caused almost the same level of stroke index in the dynamics of the examination $\left(p_{1}>0.05\right)$. At the same time, in patients with diabetes after 3 months under the conditions of zofenopril, the value of stroke index became statistically significantly higher than under the conditions of ramipril (by $19.2 \%, p_{2}<0.05$ ). Comparison of both observation groups showed that after 3 months the value of ejection fraction of left ventricle was significantly higher in patients with diabetes compared with patients without diabetes $(13.0 \%, p<0.05)$. Comparison of groups of patients depending on the antihypertensive drugs used showed that in patients without diabetes after 3 months of follow-up zofenopril caused a statistically significantly higher value of ejection fraction of left ventricle compared with patients receiving ramipril $\left(16.8 \%, \mathrm{p}_{1}<0.05\right)$.

Conclusions. Thus, our studies revealed a differentiated effect of ramipril and zofenopril on heart rate in myocardial infarction depending on the presence of diabetes. The obtained data on the restructuring of intracardiac hemodynamics in patients with concomitant diabetes indicate a higher effect of the use of zofenopril, while in patients without concomitant diabetes - ramipril.

KEY WORDS: myocardial infarction; ramipril; zofenopril; diabetes mellitus; hypertension. 